\title{
Can Peripheral Hearing Justify the Speech Disorders in Children with Operated Cleft Palate?
}

\author{
Jaqueline Lourenço Cerom ${ }^{1}$ Camila de Cássia Macedo ${ }^{2}$ Mariza Ribeiro Feniman ${ }^{3}$
}

${ }^{1}$ Department of Speech-Language Pathology and Audiology, Bauru
School of Dentistry, Universidade de São Paulo, Bauru, SP, Brazil
2 Hospital for Rehabilitation of Craniofacial Anomalies, Universidade
de São Paulo, Bauru, SP, Brazil
${ }^{3}$ Department of Speech-Language Pathology and Audiology, Bauru
School of Dentistry, Universidade de São Paulo, Bauru, SP, Brazil

Int Arch Otorhinolaryngol 2014;18:27-35.

\begin{abstract}
Address for correspondence Mariza Ribeiro Feniman, PhD, Departamento de Fonoaudiologia, Universidade de São PauloCampus USP Bauru-Alameda Dr. Octávio Pinheiro Brisolla, 9-75-Bauru / SP, Brazil 17012-901 (e-mail: feniman@usp.br).
\end{abstract}

\begin{abstract}
Keywords

- hearing loss

- cleft palate

- speech

Introduction Any impairment in the hearing ability of a child with cleft lip and palate may cause difficulties in receptive and expressive language.

Purpose Check the association between velopharyngeal dysfunction (VPD), compensatory articulation (CA), and peripheral hearing loss in children with cleft palate surgery. Methods Retrospective study with 60 children (group 1: presence of VPD and CA; group 2: absence of VPD, presence of CA; group 3: presence of VDP, absence of CA; group 4: absence of $\mathrm{VPD}$ and $(\mathrm{A})$, age 4 to 5 years old, with cleft palate surgery, through the analysis of the hearing, VP, and speech evaluations.

Results Group 4 presented $80 \%$ normal hearing; group 1 had $60 \%$ hearing loss. The conductive hearing loss type was the most frequent. The glottal stop was the most frequent in group 1 and the middorsum palatal plosive in group 2. There was no significant association $(p=0.05)$ between hearing loss and the presence of compensatory articulations (groups 2 and 4), nor between hearing loss and the presence of VPD (groups 3 and $4 ; p=0.12)$. Statistical significance $(p=0.025)$ was found when the group with VPD was associated with the group with CA, that is, group 1 with the control group (group 4).

Conclusion Significant association between peripheral hearing loss, compensatory articulations, and VPD was verified for the children in group 1, which not only presented compensatory articulations but also VPD.
\end{abstract}

\section{Introduction}

Cleft lip and palate (CLP) is one of the most common congenital malformations in the human race and is caused by a lack of fusion of facial processes during the embryonic and early fetal period. The anatomic condition presents itself as a cleft on the lip and/or palate, occurring at a frequency of 1:7,000 births. ${ }^{1}$ In Brazil, it is estimated that CLP occurs in 1.24 to 1.54 of 1,000 live births. ${ }^{2-4}$

A cleft palate can negatively affect the expressive language of the patient, as it is common for individuals with CLP to present phonoaudiological alterations with manifestations in speech, voice, language, and hearing. Thus, the interest in studying this population is growing.

The velopharyngeal structures are responsible for the distributions of expiratory airflow and acoustical vibration in the oral cavity, which affects the production of the oral sounds of speech, and in the nasal cavity, which affects the production of nasal sounds. The soft palate, the lateral walls, and the posterior pharyngeal wall function as a sphincter that closes for the production of oral sounds, preventing communication between the oral and nasal cavities during normal received

May 27, 2013

accepted

July 11, 2013
DOI http://dx.doi.org/

10.1055/s-0033-1358582. ISSN 1809-9777.
Copyright ( $\odot 2014$ by Thieme Publicações License terms Ltda, Rio de Janeiro, Brazil

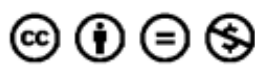


velopharyngeal function. However, inadequate velopharyngeal closure, also called velopharyngeal dysfunction (VPD), can result from the lack of soft palate tissue, called velopharyngeal insufficiency, or lack of muscular competence in the movement of velopharyngeal structures, known as velopharyngeal incompetence, or it may also be a consequence of bad articulatory habits learned in childhood and not reflecting physical or neuromuscular changes. ${ }^{5-7}$ Thus, VPD compromises speech in different ways, which can lead to hypernasality, nasal air emission, weak intraoral pressure, and compensatory articulations (CAs). ${ }^{8}$ The main cause of VPD is CLP and may persist even after primary surgery of the palate. $^{9}$

CAs can be a strategy to compensate for the inability to impose pressure in the oral cavity. Compensatory adjustments involved in using "atypical" points of articulation become part of the speech pattern. In terms of aerodynamics, the flaw in articulation performance of the velopharyngeal structures has as the main effect the generation of an intraoral pressure at levels that are insufficient to produce plosive, fricative, and affricate consonants, with nasal emission of expiratory air. Thus, subjects with VPD often replace the orally articulated sounds by articulated sounds at points behind the impairment, in an unconscious attempt to approximate the acoustic result to what they consider a normal sound. ${ }^{10}$

The most frequent CAs, secondary to VPD, are glottal stop, pharyngeal fricative, pharyngeal plosive, velar fricative, middorsum palatal plosive, and posterior nasal fricative. ${ }^{11,12}$

The knowledge of such alterations in this population not only helps improve diagnostic procedures but also contributes to the process of prevention and therapy and to the establishment of proper conduct.

With regard to hearing, subjects with a cleft palate tend to exhibit the recurrent condition of otitis media. This picture is almost universal in this population, because there is a malfunction of the tensor muscle of the soft palate, responsible for the opening and closing mechanism of the auditory tube, causing inadequate ventilation in the middle ear, leaving it more susceptible to infections and to the presence of otitis media with effusion. Currently, otitis media with effusion constitutes one of the most common causes of hypoacusis, generally of the conductive type, often bilateral in children under 10 years of age with congenital anomalies, mainly in those with CLP. ${ }^{13}$ It occurs quietly, without tympanic membrane perforation and without active infection of the middle ear. $^{14}$

Susceptibility to middle ear disorders in individuals with cleft palate is emphasized in the literature, not only due to structural abnormalities in the proximity of the eustachian tube leading to a tube dysfunction and otitis media with effusion, but also because these factors are responsible for a high occurrence of temporary hearing loss in this population. ${ }^{15-17}$ Scientific studies report that the population with a cleft palate, when compared with that without a cleft palate, has a higher incidence of hearing loss, otologic complications, VPD, and CAs, which are risk indicators to the development of auditory, language, speech, and learning processing.
Considering that the ability to listen is a skill that depends on the innate biological capacity of speakers as well as their experiences listening to language damage in this ability can result in receptive and expressive language difficulties in a child with a cleft palate. Thus, would the hearing loss present in children with this type of malformation be responsible for speech disorders, or lead to its permanence, even after surgical correction of CLP?

The present study aims to investigate the association between VPD, CA, and peripheral hearing loss in subjects with CLP surgery.

\section{Materials and Methods}

\section{Subjects}

After obtaining approval of the Research Ethics Committee of the Hospital for Rehabilitation of Cranio-Facial Anomalies (HRAC-USP) number 74/2011 on March 29, 2011, the Data Processing Center of HRAC-USP provided a list of patients with left unilateral incisive transforamen cleft (FTIUE) surgery ${ }^{18}$ registered in this hospital. This type of cleft was chosen because it is the most frequent in this hospital.

The records of 60 patients with FTIUE of both sexes, from 4 to 5 years old, were selected. These were classified into four groups: G1 (experimental group 1), children presenting VPD and CAs; G2 (experimental group 2), children without VPD but with CAs; G3 (experimental group 3), children presenting VPD but without CAs; G4 (experimental group 4), children without VPD and without CAs. Each of the four groups consisted of 15 children, 7 boys and 8 girls. The mean age of the groups was 55.18 months, with a standard deviation of 2 months.

For the formation of the groups, VPD was considered present in the subject who presented maximum score in the analysis of the phonoarticulatory assessment (reported on the medical report). CA was considered present in the subject who presented at least one type described on the phonoarticulatory assessment.

The criteria for inclusion in the sample were medical records of patient who had left FTIUE surgery, who had palatoplasty in the age threshold from 9 to 18 months years old, and whose files contained the signature of parents and patients on the authorization term on the record. As exclusion criteria, the following were considered: presence of associated syndromes and lack of documentation of the audiologic, otorhinolaryngologic, speech, and VPD evaluation on the record.

\section{Methods}

The study was retrospective and without the identification of the patients. After the selection of the records, an analysis of the child's hearing assessment was made, through otorhinolaryngologic assessment and audiologic evaluation of the velopharyngeal function and of speech. As it is routine to perform many of these patients' evaluations over their treatment at the hospital, only the evaluations that were performed between the ages of 4 and 5 years ( 48 to 60 months) were considered for this study. 
In the otorhinolaryngologic evaluation, emphasis was on pneumatic otoscopy prior to the audiologic evaluation, performed by an otorhinolaryngologist from the hospital, using a Heine K 100 Diagnostic Otoscope (Germany), as well as the otologic surgeries performed.

The otoscopies were classified as positive when the following were present: middle ear fluid, tympanic membrane immobility on insufflation, use of ventilation tube, tympanic perforation, cholesteatoma, tympanic opacification, tympanic retraction, tympanosclerosis, and otorrhea; otoscopies were classified as negative when the tympanic membrane was intact and shiny. The history of otologic surgery made was noted in terms of presence or absence, place of performance, number, and laterality.

In the audiologic evaluation, the audiologic interview was verified, and tonal threshold audiometry was performed with TDH-39 headphones and Midimate 622 Diagnostic Audiometer Madsen (Copenhagen, DK).

In the audiologic interview, emphasis was on the occurrence of hearing complaints, as well as the hearing history of each subject. Hearing complaints were classified as present or absent. The complaints presented were in relation to hypoacusis, otalgia, otorrhea, and itching. The hearing history was classified as positive when there were hearing risk indicators and negative when the hearing reactions were within normal standards. The findings regarding the risk indicators were otologic diseases, parental consanguinity, and deafness in the family, while the negative findings were reaction to environmental sounds and reaction to the sounds of speech and wakening reaction expected for the age. In the tonal threshold audiometry, absence or presence of hearing loss was considered. When present, it was classified in terms of laterality, type (conductive, mixed, and sensorineural), degree (slight from 15 to $30 \mathrm{~dB}$, moderate from 31 to $60 \mathrm{~dB}$, severe from 61 to $90 \mathrm{~dB}$, and profound, over $90 \mathrm{~dB}) .^{19}$

In the velopharyngeal function evaluation, the presence or absence of dysfunction (VPD) was verified. Maximum score, that is, 10 and 10 for the nasal air emission test (mirror) and hypernasality test (cul-de-sac), suggests the presence of VPD.

In the speech evaluation, the existence of CAs in at least one phoneme was verified. When present, the type presented was considered: glottal stop, mid-dorsum palatal plosive, pharyngeal plosive, pharyngeal fricative, posterior nasal fricative, nasal fricative, and velar fricative. The phonemes that were substituted by the CAs were also considered.

The hearing, velopharyngeal function, and speech evaluations were performed by properly trained audiologists and speech-language therapists from the multidisciplinary team of the hospital.

The velopharyngeal and speech functions were analyzed to form the groups proposed by the study. The information obtained from the records were analyzed and processed in terms of presence/absence of VPD; presence/absence of CAs and their respective characterization; presence, type, degree, and laterality of the hearing loss. The chi-square statistical test was used to verify the existence of an association between VPD/CA disorders/peripheral hearing loss $(p \geq 0.05)$.

\section{Results}

\section{Hearing and Otorhinolaryngologic Evaluation (Otoscopy and Otologic Surgery)}

G2 and G3 had a higher percentage of otoscopy showing an intact and shiny tympanic membrane. - Tables 1, 2, 3, and 4 demonstrate the distribution of otoscopy results, according to each group. Seventy percent of the total sample of the study presented some type of alteration in the otoscopy.

Among the positive otoscopies, the most common alterations found in G1 and G4 were tympanic retraction and opacification. - Table $\mathbf{5}$ shows the positive findings and their distribution in the four groups that were studied.

All groups reported having at least one otologic surgery; G1 and G3 underwent the most.

\section{Audiologic Evaluation}

\section{Interview}

The occurrence of $76.6 \%$ absence of hearing complaint was verified in the analysis of the data from the audiologic interview. G1 had the most complaints, followed by G2 (-Tables 1, 2, 3 and 4). Although most of the participants presented a negative history of hearing loss, both G1 and G4 showed $40 \%$ of positive history; otologic diseases, present in all groups, were more prevalent in G1, G3, and G4.

\section{Tonal Threshold Audiometry}

G4 (control group) presented a higher occurrence of subjects with normal hearing (80\%), and G1 (with VPD and CA) presented a higher occurrence of hearing loss (60\%). The conductive type was the most frequent hearing loss type in the four groups. None of the subjects presented mixed loss. The bilateral hearing loss was the most frequent. Regarding the degree of hearing loss, there was a predominance of slight conductive loss ( - Tables $\mathbf{1}, \mathbf{2}, \mathbf{3}$, and $\mathbf{4}$ ).

\section{Speech Evaluation}

G1 and G2 were formed by children who presented at least one type of CA. Glottal stop was the most frequent in G1; in G2, it was the mid-dorsum palatal plosive (-Tables 1 and $\mathbf{2}$ ). Only one child from G1 presented two different CAs (-Table 1). There was no statistically significant association ( $p=0.05$ ) between the presence of hearing loss and the presence of CAs (G2/G4) and between hearing loss and the presence of VPD $(\mathrm{G} 3 / \mathrm{G} 4 ; p=0.12)$. However, statistical significance $(p=0.025)$ was verified in G1 compared with G4.

\section{Discussion}

The present study demonstrates that altered otoscopies (positive) were prevalent in G1 (-Table 1), with a higher incidence of presence of tympanic membrane retraction and opacification. This finding can lead us to the conclusion that VPD as well as CAs present in this group could be justified by these otorhinolaryngologic alterations and 
30 Speech Disorders in Children with Operated Cleft Palate Cerom et al.

Table 1 Distribution of otoscopy, hearing complaint, hearing loss, compensatory articulations, phonemes, and velopharyngeal dysfunction data, according to each subject from group 1

\begin{tabular}{|c|c|c|c|c|c|c|}
\hline Ото & $\mathrm{QA}$ & $\mathrm{PA}$ & TGPA & CA & Phonemes & VPD \\
\hline $\mathrm{Neg}$ & $\mathrm{P}$ & A & $\mathrm{Nl}$ bilateral & GG & $|\mathrm{t} /,| \mathrm{k} \mid$ & $P$ \\
\hline Pos & $\mathrm{P}$ & $P$ & PC slight bilateral & FNP & $|s|,|z|$ & $P$ \\
\hline Pos & $\mathrm{P}$ & $\mathrm{P}$ & PC slight unilateral OE & $\mathrm{FF}$ & $|s|,\left|\int\right|$ & $\mathrm{P}$ \\
\hline Pos & $\mathrm{P}$ & $\mathrm{P}$ & PC slight bilateral & GG, FF & $|\mathrm{p}|,|\mathrm{t}|,|\mathrm{k}|,|\mathrm{s}|$ & $\mathrm{P}$ \\
\hline Neg & $\mathrm{P}$ & A & Nl bilateral & $\mathrm{FF}$ & $|\mathrm{p}|,|\mathrm{t}|,|\mathrm{k}|,|\mathrm{g}|,|\mathrm{f}|,|\mathrm{s}|,\left|\int\right|$ & $\mathrm{P}$ \\
\hline Pos & A & $\mathrm{P}$ & PC Mod unilateral OE & PDMP & $|\mathrm{t} /,| \mathrm{d} /$ & $\mathrm{P}$ \\
\hline Pos & A & A & Nl bilateral & GG & $|\mathrm{p}|,|\mathrm{t}|,|\mathrm{k}|$ & $P$ \\
\hline Pos & A & $\mathrm{P}$ & PSN slight unilateral OD & GG & $|\mathrm{t} /,| \mathrm{k} \mid$ & $P$ \\
\hline Pos & A & A & Nl bilateral & GG & $\mid \mathrm{k} /$, & $\mathrm{P}$ \\
\hline Pos & A & $\mathrm{P}$ & PC slight unilateral OE & $\mathrm{FF}$ & $|s|,\left|\int\right|$ & $\mathrm{P}$ \\
\hline $\mathrm{Neg}$ & A & $\mathrm{A}$ & Nl bilateral & GG & $|\mathrm{p} /,| \mathrm{t} /,|\mathrm{k} /,| \mathrm{g} \mid$ & $P$ \\
\hline Pos & A & A & $\mathrm{NI}$ bilateral & $\mathrm{FF}$ & $\left|\int\right|,\left|\mathrm{t} \int\right|$ & $\mathrm{P}$ \\
\hline Pos & A & $\mathrm{P}$ & PC slight bilateral & $\mathrm{FV}$ & $|s|,\left|\int\right|,|z|,|j|$ & $\mathrm{P}$ \\
\hline Pos & A & $\mathrm{P}$ & PC slight bilateral & GG & $|\mathrm{p} /,| \mathrm{t}|,| \mathrm{k} \mid$ & $\mathrm{P}$ \\
\hline Pos & A & $P$ & PC slight bilateral OD & $\mathrm{FF}$ & $|s|$ & $P$ \\
\hline
\end{tabular}

Abbreviations: A, absent; CA, compensatory articulation; FF, pharyngeal fricative; FNP, posterior nasal fricative; FV, velar fricative; GG, glottal stop; Mod, moderate; Neg, negative; NI, normal; OTO, otoscopy; OD, right ear; OE, left ear; P, present; PA, hearing loss; PC, conductive loss; PDMP, middorsum palatal plosive; PSN, sensorineural loss; Pos, positive; P, present; QA, hearing complaints; TGPA, hearing loss type and degree; VPD, velopharyngeal dysfunction.

Table 2 Distribution of otoscopy, hearing complaint, hearing loss, compensatory articulations, phonemes, and velopharyngeal dysfunction data, according to each subject from group 2

\begin{tabular}{|c|c|c|c|c|c|c|}
\hline ото & QA & PA & TGPA & CA & Phonemes & VPD \\
\hline Pos & $P$ & $\mathrm{P}$ & PM Mod OD, PC slight OE & GG & $|\mathrm{p} /,| \mathrm{t}|,| \mathrm{k} \mid$ & A \\
\hline Pos & $P$ & $P$ & PC slight bilateral & PDMP & /d/ & A \\
\hline $\mathrm{Neg}$ & $\mathrm{P}$ & $\mathrm{A}$ & NI bilateral & PDMP & $\mid \mathrm{t} /, / \mathrm{d} /$ & A \\
\hline Pos & $\mathrm{P}$ & $\mathrm{P}$ & PC slight OE & PDMP & $|\mathrm{t} /,| \mathrm{d} /, / \mathrm{n} \mid$ & A \\
\hline Neg & A & A & $\mathrm{Nl}$ bilateral & FNP & $|\mathrm{f}|,|\mathrm{s}|,\left|\int\right|,|\mathrm{z}|$ & A \\
\hline Pos & A & $\mathrm{P}$ & PC slight bilateral & PDMP & $\mid \mathrm{t} /, / \mathrm{d} /$ & A \\
\hline Pos & A & $\mathrm{P}$ & PC slight OE & PDMP & $\mid \mathrm{t} /, / \mathrm{d} /, / \mathrm{n} /$, & A \\
\hline $\mathrm{Neg}$ & A & A & $\mathrm{Nl}$ bilateral & FNP & $|\mathrm{f}|,|\mathrm{v}|$ & A \\
\hline Pos & A & $\mathrm{P}$ & PC slight bilateral & GG & $\mid \mathrm{k} /$ & A \\
\hline $\mathrm{Neg}$ & A & $\mathrm{A}$ & $\mathrm{Nl}$ bilateral & FNP & $|s|,\left|\int\right|,|z|,|j|$ & A \\
\hline Pos & A & $P$ & PC slight bilateral & PDMP & $|\mathrm{t} /,| \mathrm{d} \mid$ & A \\
\hline Pos & A & $\mathrm{P}$ & PC slight OE & FNP & $|s|$ & A \\
\hline $\mathrm{Neg}$ & A & A & $\mathrm{Nl}$ bilateral & PDMP & $|t|,|d|$ & A \\
\hline Pos & A & $\mathrm{A}$ & Nl bilateral & $\mathrm{FV}$ & $|s|$ & A \\
\hline $\mathrm{Neg}$ & A & A & NI bilateral & GG & $\mid \mathrm{k} /$ & A \\
\hline
\end{tabular}

Abbreviations: A, absent; CA, compensatory articulation; FNP, posterior nasal fricative; FV, velar fricative; GG, glottal stop; Mod, moderate; Neg, negative; NI, normal; OTO, otoscopy; OD, right ear; OE, left ear; PDMP, mid-dorsum palatal plosive; PM, mixed loss; PC, conductive loss; QA, hearing complaints; PA, hearing loss; Pos, positive; P, present; TGPA, hearing loss type and degree; VPD, velopharyngeal dysfunction. 
Table 3 Distribution of otoscopy, hearing complaint, hearing loss, compensatory articulations, phonemes, and velopharyngeal dysfunction data, according to each subject from G3

\begin{tabular}{|c|c|c|c|c|c|c|}
\hline Ото & $\mathrm{QA}$ & PA & TGPA & CA & Phonemes & VPD \\
\hline Pos & A & $\mathrm{P}$ & PC Mod Unilateral OE & A & - & $\mathrm{P}$ \\
\hline $\mathrm{Neg}$ & A & A & Nl bilateral & A & - & $P$ \\
\hline $\mathrm{Neg}$ & A & A & $\mathrm{Nl}$ bilateral & A & - & $\mathrm{P}$ \\
\hline Pos & $A$ & $P$ & PC slight bilateral & A & - & $\mathrm{P}$ \\
\hline Pos & A & $P$ & PC slight unilateral OE & A & - & $P$ \\
\hline $\mathrm{Neg}$ & A & A & $\mathrm{Nl}$ bilateral & A & - & $\mathrm{P}$ \\
\hline $\mathrm{Neg}$ & A & A & Nl bilateral & A & - & $P$ \\
\hline Pos & $P$ & $P$ & PC slight bilateral & A & 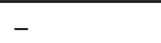 & $P$ \\
\hline $\mathrm{Neg}$ & $\mathrm{P}$ & A & Nl bilateral & A & - & $\mathrm{P}$ \\
\hline Pos & A & $\mathrm{P}$ & PC slight bilateral & A & - & $P$ \\
\hline Pos & A & A & NI bilateral & A & - & $\mathrm{P}$ \\
\hline $\mathrm{Neg}$ & A & A & Nl bilateral & A & - & $\mathrm{P}$ \\
\hline Pos & A & $P$ & PC slight unilateral OE & A & - & $P$ \\
\hline Pos & $\mathrm{P}$ & $\mathrm{P}$ & PC slight unilateral OD & A & - & $\mathrm{P}$ \\
\hline Pos & A & A & Nl bilateral & A & - & $\mathrm{P}$ \\
\hline
\end{tabular}

Abbreviations: A, absent; CA, compensatory articulation; Mod, moderate; Neg, negative; NI, normal; OD, right ear; OE, left ear; OTO, otoscopy; PA, hearing loss; PC, conductive loss; Pos, positive; P, present; QA, hearing complaints; TGPA, hearing loss type and degree; VPD, velopharyngeal dysfunction.

Table 4 Distribution of otoscopy, hearing complaint, hearing loss, compensatory articulations, phonemes, and velopharyngeal dysfunction data, according to each subject from G4

\begin{tabular}{|c|c|c|c|c|c|c|}
\hline Ото & $\mathrm{QA}$ & $\mathrm{PA}$ & TGPA & CA & Phonemes & VPD \\
\hline Pos & A & $P$ & PC slight bilateral & A & - & A \\
\hline Neg & A & A & NI bilateral & A & - & A \\
\hline Pos & A & $\mathrm{P}$ & PC slight bilateral & A & - & A \\
\hline Pos & A & A & NI bilateral & A & - & A \\
\hline Pos & A & $A$ & $\mathrm{Nl}$ bilateral & A & - & $\mathrm{A}$ \\
\hline Pos & A & A & $\mathrm{NI}$ bilateral & A & - & A \\
\hline Pos & A & A & NI bilateral & A & - & A \\
\hline Pos & $A$ & $A$ & $\mathrm{Nl}$ bilateral & $A$ & - & $A$ \\
\hline $\mathrm{Neg}$ & A & A & $\mathrm{NI}$ bilateral & A & - & A \\
\hline Pos & A & A & NI bilateral & A & - & A \\
\hline Pos & $\mathrm{P}$ & A & NI bilateral & A & - & A \\
\hline Pos & A & A & NI bilateral & A & - & A \\
\hline Pos & A & $A$ & NI bilateral & A & - & A \\
\hline Neg & $\mathrm{P}$ & A & Nl bilateral & A & - & A \\
\hline Pos & A & $P$ & PC slight bilateral & A & - & A \\
\hline
\end{tabular}

Abbreviations: A, absent; CA, compensatory articulation; Neg, negative; NI, normal; OTO, otoscopy; PA, hearing loss; PC, conductive loss; Pos, positive; P, present; QA, hearing complaints; TGPA, hearing loss type and degree; VPD, velopharyngeal dysfunction.

could lead to damage of the sampled children's hearing, as opacification and tympanic membrane retraction, along with other items, are evidence of the presence of effusion in the middle ear. ${ }^{20}$ However, a similar result (-Table 4) can be visualized for the control group, in which the patients with CLP do not manifest VPD nor CAs. Opacification and retraction were also reported in other studies. $^{21,22}$ 
Table 5 Distribution of the positive otoscopic findings according to each group and ear

\begin{tabular}{|l|l|l|l|l|l|l|l|l|l|}
\hline & & G1 & G2 & & G3 & & G4 & & Total \\
\hline & OD & OE & OD & OE & OD & OE & OD & OE & \\
\hline Fluid in the middle ear & 1 & 1 & 1 & 1 & 1 & 2 & 4 & 4 & 15 \\
\hline Still in the insufflation & 3 & 4 & 3 & 2 & 2 & 5 & 4 & 2 & 25 \\
\hline Ventilation tube & - & - & 1 & 1 & 1 & 1 & - & - & 4 \\
\hline Tympanic perforation & - & 1 & - & 1 & 1 & - & 1 & 1 & 5 \\
\hline Cholesteatoma & - & - & - & - & - & - & 1 & 1 & 2 \\
\hline Opacification & 7 & 5 & 1 & 1 & 4 & 5 & 8 & 8 & 39 \\
\hline Tympanic retraction & 10 & 8 & 1 & 1 & 4 & 6 & 8 & 7 & 45 \\
\hline Tympanosclerosis & 5 & 3 & 1 & 2 & 1 & - & 1 & 2 & 15 \\
\hline Otorrhea & - & - & - & 1 & - & - & 1 & 1 & 3 \\
\hline Total & 26 & 22 & 8 & 10 & 14 & 19 & 28 & 26 & \\
\hline
\end{tabular}

Abbreviations: G1, group with and compensatory articulations; G2, group without velopharyngeal dysfunction and with compensatory articulations; G3, group with velopharyngeal dysfunction and without compensatory articulations; G4, control group; OD, right ear; OE, left ear.

Frequently, middle ear dysfunction are treated with surgical intervention for insertion of ventilation tube to drain secretion and better ventilate the middle ear. ${ }^{23}$ In the four groups investigated in this study, there were children who had received ventilation tubes at least once, which could also justify otoscopic findings, because the surgery with the insertion of a ventilation tube has long-term damage, such as perforation and retraction of the tympanic membrane, chronic otitis media, and hearing impairment. ${ }^{15,24}$ Moreover, results show that children who presented VPD (G1 and G3) underwent the most microsurgeries in relation to the others. Studies that pointed out this relationship were not found in the literature.

More than $70 \%$ of the sample had no hearing complaints ( - Tables 1, 2, 3, and 4). This can be explained by the fact that the sample was composed of children and this complaint was answered during the interview with the parents. Hearing problems often go unnoticed in CLP, as episodes of otitis media occur silently. ${ }^{14}$ The finding is corroborated by researchers ${ }^{25,26}$ who describe that most subjects with CLP did not present complaints regarding hearing. Researchers ${ }^{27}$ identified $3.8 \%$ of patients with CLP, reporting hearing complaints of the 239 who presented unilateral or bilateral hearing loss.

When the history of the hearing of each child from this study was investigated, we obtained a higher occurrence of negative history for hearing loss ( $\mathbf{- T a b l e s} \mathbf{1}, \mathbf{2}, \mathbf{3}$, and $\mathbf{4}$ ). In those who had a positive history, otologic diseases were the most frequent risk indicators, present in all groups. Schol$\operatorname{ars}^{28}$ have identified the presence of other risk indicators for hearing, besides the presence of CLP, by studying 100 infants with this type of malformation; the main indicator that influenced the performance of these infants in the verbal recognition test was positive history of otologic diseases.

When subjects with CLP are compared with subjects without this malformation, there is a significantly higher prevalence of middle ear disorders and a higher incidence of hearing loss, ${ }^{17}$ which has been demonstrated by researchers. ${ }^{29-31} \mathrm{~A}$ significant percentage of hearing loss was also demonstrated in this study for all the sampled groups, including the control group (children with CLP only), in which, despite having a lower incidence, some cases of hearing loss were diagnosed (-Table 4). Greater hearing impairment, evidenced by the presence of hearing loss, has been evidenced for groups of patients with CLP with VPD and/ or CAs present (- Tables $\mathbf{1 , 2}$ and $\mathbf{3}$ ), but without statistical significance.

Although the literature ${ }^{32,33}$ reports the presence of all types of hearing loss in people with this type of malformation, hearing loss in this study was predominantly mild conductive and bilateral (-Tables 1, 2, 3, and 4) loss, in agreement with the findings in the literature for subjects with CLP. The sensorineural hearing loss diagnosed in only one case in G1 must be related to other etiopathogenetic factors not specifically related to the CLP deformity.

Hearing loss, even if mild degree, impairs sound wave conduction and compromises the perception and the understanding of speech segments ${ }^{34,35}$ as well as interfere with performance tests that assess the ability of sustained auditory attention. ${ }^{36}$

In agreement with the literature, ${ }^{11,12}$ which reports glottal stop, pharyngeal fricative, pharyngeal plosive, velar fricative, posterior nasal fricative, and mid-dorsum palatal plosive among CAs commonly found in the speech of individuals with a cleft palate, the present study showed, with the exception of the pharyngeal plosive, the presence of other CAs ( - Tables 1, 2). The literature describes the occurrence of CA in plosive and fricative phonemes due to the relationship with the high intraoral pressure, which involves the production of such kinds of phonemes. ${ }^{37}$ The highest percentage of glottal stop occurrence of the sampled population, observed prevalently in G1 (- Table 1), reinforces what is described in the literature as the most common type of CA produced by 
individuals who have cleft palate and/or VPD. ${ }^{12,38,39}$ For G2

(-Table 2), mid-dorsum palatal plosive was prevalent.

Glottal stop or glottal occlusion is a glottal sound like a hard vocal attack, produced by the abrupt adduction and abduction of the vocal fold, with the goal of generating plosion in the glottis, by a sudden and sharp increase of the subglottic pressure. ${ }^{37}$ It occurs in substitution of the consonants that require higher intraoral pressure, in particular for the occlusive consonants and its related voiced consonants. ${ }^{11}$ In the present study it occurred in the occlusive phonemes $/ \mathrm{p} /$ , /t/, /k/, and /g/ in G1 and G2 (-Tables 1 and 2).

Mid-dorsum palatal plosive happens when the middle of the tongue contacts the hard palate and is observed in the speech of subjects with CLP and/or VPD. ${ }^{11}$ The literature reports that this kind of $C A$ is observed in substitution of the sounds $/ \mathrm{t} /, / \mathrm{d} /, / \mathrm{k} /$, or $/ \mathrm{g} /$, when associated with VPD or palatal fistula. ${ }^{40}$ Besides, research ${ }^{41}$ has shown that middorsum palatal plosive can only be associated with VPD when it occurs in substitution to alveolar sounds. In this study, it was found as a replacement to the phonemes $/ \mathrm{t} /, \mathrm{d} /$, and /n/ in G2 (- Table 2), the group with CLP but without VPD, or fistula, both checked by evaluating constant talk in the records analyzed. Therefore, one may conclude that its occurrence is due to occlusal changes as demonstrated in the study, ${ }^{11}$ but this aspect was not investigated in this study.

Pharyngeal fricative CA, the third most frequent in the present study, occurred only in G1 ( - Table $\mathbf{1}$ ) and is associated with the presence of CLP and/or VPD, in substitution of the fricative consonants, ${ }^{42}$ in agreement to what happened on phonemes $/ \mathrm{f} /, / \mathrm{s} /$, and $/ \mathrm{j} /$ in this work. They are produced by the friction of the tongue base with the posterior pharyngeal wall, with the goal of generating airflow constriction, resulting in friction. ${ }^{39}$

Also in substitution of the fricative consonants, ${ }^{11,40}$ the posterior nasal fricative appears in this study as the fourth most frequent and is produced when the posterior portion of the tongue and the soft palate are positioned to produce friction on the velopharyngeal mechanism, without its complete closure. $^{43}$

The velar fricative CA, which appears less frequently in this study, in agreement with the literature, ${ }^{44}$ occurred in the fricatives $|\mathrm{s} /,| \mathrm{J}|,| \mathrm{z} \mid$, and $/ \mathrm{j} /$. In association with the presence of cleft palate and/or DVF, this CA is produced by the friction from the contact of the dorsum of the tongue with the soft palate. $^{11,40,44}$

The present study showed no CAs in liquid phonemes, although clinical evidence shows that many subjects with FP may present posteriorization or inappropriate tongue elevation and tongue clicks while emitting liquid lingual phonemes, such as $/ \mathrm{r} /$ and $/ 1 / .^{45}$

Thus, in view of the analysis of peripheral hearing evaluations through otorhinolaryngologic and audiologic exams and of the velopharyngeal function and speech of children with CLP, the study demonstrates the absence of significance of associated hearing loss with the presence of CA disorders $(p=0.05)$, as well as the presence of hearing loss with the presence of VPD $(p=0.12)$. This result could be attributed to the fact that our sample was small, due to the difficulty of composing the group without VPD and with CA. Furthermore, this work reinforces the conclusion of a study ${ }^{46}$ that evaluated 70 children, age 7 to 11 years, with this type of malformation, with CA present and related to the velopharyngeal function, which found no significant difference between the presence of CAs in subjects with and without hearing loss; even through the study of hearing thresholds and analysis of the velopharyngeal function, the author found that the better or worse functioning of the velopharyngeal sphincter was not associated with the conditions of the peripheral auditory conditions of school-aged children.

Normal hearing is essential for the acquisition of oral language and effective verbal communication, and any deficit in the auditory system, either congenital or acquired, affects the transmission and/or perception of sound. ${ }^{47}$

The results of this study suggest that peripheral hearing loss, represented here by a mild degree of conductive hearing loss, were not related to CAs or VPD in children with CLP, as long as CA and VPD did not co-occur. Findings, however, show statistically significant differences for children who had CAs in combination to VPD (G1). Could this difference observed between groups 1 and 2 and between groups 1 and 3 be explained with regard to the type of VPD present or the variability in the type of CAs and speech therapy, which were not controlled in the present study? Or, would these children with CLP from group 2 not be correctly noticing the phonemes, which are being substituted by CAs? Or are the ones from group 3 not having the correct acoustic perception of the nasopharynx and oropharynx coupling, revealed by the DVF presented? Researchers ${ }^{47}$ report that the auditory deficit has a profound effect in some of the abilities to listen and understand speech.

Sensory deprivation caused by middle ear disorders such as conductive hearing loss ${ }^{15,48}$ may lead to changes in different core skills. ${ }^{49,50}$

The literature $\mathrm{e}^{49-57}$ has grown in the investigation of the evaluation of the central hearing abilities, through questionnaires and behavioral test of the hearing processing in subjects with this kind of malformation. However, it is limited when the evaluation of these abilities is related to speech disorders and to VPD present in these subjects.

Thus, there is a need to continue this study, not only with the evaluation of the peripheral auditory function but also with the research of the central auditory function, through the assessment of central auditory skills, in addition to increasing the size of the sample, controlling the type of VPD and CAs and speech therapy, aiming to clarify the still obscure points in the diagnostic process, and providing data that support the process of intervention in this population.

\section{Conclusion}

The study concluded that association between peripheral hearing loss, CAs, and VPD were not found when expressed separately. However, statistical significance was found when the sampled children presented not only CAs but also VPD. 


\section{References}

1 Murray JC. Gene/environment causes of cleft lip and/or palate. Clin Genet 2002;61(4):248-256

2 Nagem Filho H, Moraes N, Rocha RGF. Contribuições para o estudo da prevalência das más formações congênitas lábio-palatais na população escolar de Bauru. Rev Fac Odontol Sao Paulo 1968;6(2): 111-128

3 França CMC, Locks A. Incidência das fissuras lábio-palatinas de crianças nascidas na cidade de Joinville (SC) no período de 1994 a 2000. J Bras Ortodon Ortop Facial 2003;8(47):429-436

4 Nunes LMN, Queluz DP, Pereira AC. Prevalence of oral cleft in Campos dos Goytacazes-RJ, 1999-2004. Rev Bras Epidemiol 2007; 10(1):109-116

5 Trost-Cardamone JE. Coming to terms with VPI: a response to Loney and Bloem. Cleft Palate J 1989;26(1):68-70

6 Johns DF, Rohrich RJ, Awada M. Velopharyngeal incompetence: a guide for clinical evaluation. Plast Reconstr Surg 2003;112(7): 1890-1897, quiz 1898, 1982

7 Pinto JH, da Silva Dalben G, Pegoraro-Krook MI. Speech intelligibility of patients with cleft lip and palate after placement of speech prosthesis. Cleft Palate Craniofac J 2007;44(6):635-641

8 Genaro KF, Fukushiro AP, Suguimoto MLFCP. Avaliação dos distúrbios da fala. In: Trindade IEK, Silva Filho OG, eds. Fissuras labiopalatinas: uma abordagem interdisciplinar. São Paulo, Brasil: Santos; 2007:109-122

9 Fukushiro AP. Análise perceptiva, nasométrica e aerodinâmica da fala de indivíduos submetidos à cirurgia de retalho faríngeo para a correção da insuficiência velofaríngea [Dissertação] Bauru: Hospital de Reabilitação das Anomalias Craniofaciais, Universidade de São Paulo (USP); 2007

10 Trindade IEK, Trindade Junior AS. Avaliação funcional da inadequação velofaríngea. In: Carreirão S, Lessa S, Zanini AS, eds. Tratamento das fissuras labiopalatinas. 2a ed. Rio de Janeiro, Brasil: Revinter; 1996:223-235

11 Kummer AW. Anatomy and physiology: the orofacial structures and velopharyngeal valve. In: Cleft Palate and Craniofacial Anomalies: The Effects on Speech and Resonance. San Diego (CA): Singular; 2001

12 Peterson-Falzone SJ, Hardin-Jones MA, Karnell MP. Communication Disorders Associated with Cleft Palate. Cleft Palate Speech. 3rd ed. St. Louis, MO: Mosby; 2001:162-198

13 Sheahan P, Blayney AW. Cleft palate and otitis media with effusion: a review. Rev Laryngol Otol Rhinol (Bord) 2003;124(3):171-177

14 Acuin J. Chronic suppurative otitis media. Clin Evid (Online) 2007; 2007:0507

15 Tunçbilek G, Ozgür F, Belgin E. Audiologic and tympanometric findings in children with cleft lip and palate. Cleft Palate Craniofac J 2003;40(3):304-309

16 Arnold WH, Nohadani N, Koch KH. Morphology of the auditory tube and palatal muscles in a case of bilateral cleft palate. Cleft Palate Craniofac J 2005;42(2):197-201

17 Flynn T, Möller C, Jönsson R, Lohmander A. The high prevalence of otitis media with effusion in children with cleft lip and palate as compared to children without clefts. Int J Pediatr Otorhinolaryngol 2009;73(10):1441-1446

18 Spina V, Psillakis JM, Lapa FS, Ferreira MC[Classification of cleft lip and cleft palate. Suggested changes]. Rev Hosp Clin Fac Med Sao Paulo 1972;27(1):5-6

19 Northern JL, Downs MP. Behavioral hearing testing of children. In: Hearing in Children. 4a. ed. Baltimore, MD: Williams \& Wilkins; 1991

20 Valente MH, Esobar AMU, Grisi SJFE. Aspectos diagnósticos da otite média com derrame na faixa etária pediátrica. Rev Bras Saúde Matern Infant 2010;10(2):157-170

21 Feniman MR, Souza AG, Jorge JC, Lauris JRP. Otoscopic and tympanometric findings in infants with cleft lip and palate. Braz J Otorhinolaryngol 2008;74(2):248-252
22 Junior AT, Piazentin-Penna SHA. Ocorrência de otite média na fissura de palato submucosa: dados preliminares. Salusvita, Bauru (SP); 2006:353-362

23 Sancho Martín I, Villafruela Sanz MA, Alvarez Vicent JJ. Incidence and treatment of otitis with effusion in patients with cleft palate. Acta Otorrinolaringol Esp 1997;48(6):441-445

24 Sheahan P, Miller I, Sheahan JN, Earley MJ, Blayney AW. Incidence and outcome of middle ear disease in cleft lip and/or cleft palate. Int J Pediatr Otorhinolaryngol 2003;67(7):785-793

25 Ramana YV, Nanda V, Biswas G, Chittoria R, Ghosh S, Sharma RK. Audiological profile in older children and adolescents with unrepaired cleft palate. Cleft Palate Craniofac J 2005;42(5):570-573

26 Luthra S, Singh S, Nagarkar AN, Mahajan JK. The role of audiological diagnostics in children with cleft lip \& palate (CLP). Int J Pediatr Otorhinolaryngol 2009;73(10):1365-1367

27 Cerom JL, José MR, Azenha FSP, et al. Auditory complaints and audiologic assessment in children with surgically repaired cleft lip and palate. Int Arch Otorhinolaryngol 2013;17(2):184-188

28 Feniman MR, Daniel BT, De Vitto LP, Lemos IC, Lauris JR. Verbal recognition of infants with cleft lip and palate with and without history of risk indicators for hearing loss. Braz J Otorhinolaryngol 2008;74(4):601-605

29 Andrews PJ, Chorbachi R, Sirimanna T, Sommerlad B, Hartley BEJ. Evaluation of hearing thresholds in 3-month-old children with a cleft palate: the basis for a selective policy for ventilation tube insertion at time of palate repair. Clin Otolaryngol Allied Sci 2004; 29(1):10-17

30 Goudy S, Lott D, Canady J, Smith RJ. Conductive hearing loss and otopathology in cleft palate patients. Otolaryngol Head Neck Surg 2006;134(6):946-948

31 Lima AMF, Lauris JRP, Feniman MR. Audição de crianças com fissura labiopalatina e baixo peso: estudo comparativo. Arq Int Otorrinolaringol (Impr) 2011;15(4):461-467

32 Zambonato TC, Feniman MR, Blasca WQ, Lauris JR, Maximino LP. Profile of patients with cleft palate fitted with hearing AIDS. Braz J Otorhinolaryngol 2009;75(6):888-892

33 Cerom JL. Fissura labiopalatina: ocorrência de perda sensorioneural. [Trabalho de Conclusão de Curso] Bauru, Brasil: Universidade de São Paulo (USP); 2010

34 Klein SK, Rapin I. Perda intermitente da audição de condução e desenvolvimento da linguagem. In: Bishop D, Mogford K, eds. Desenvolvimento da linguagem em circunstâncias excepcionais. Rio de Janeiro, Brasil: Revinter; 2002:123-144

35 Zeisel AS, Roberts JE. Otitis media in young children with disabilities. Infants Young Child 2003;4(16):106-119

36 Mondelli MF, Carvalho FR, Feniman MR, Lauris JR. Mild hearing loss: performance in the Sustained Auditory Attention Ability Test. Pro Fono 2010;22(3):245-250

37 Pegoraro-Krook MI, Souza JCRD, Teles-Magalhães LC, Feniman MR. Intervenção fonoaudiológica na fissura palatina. In: Ferreira LP, Befi-Lopes DM, Limongi SCO, eds. Tratado de fonoaudiologia. São Paulo, Brasil: Roca; 2004:339-455

38 Trost-Cardamone JE. Diagnosis of specific cleft palate speech error patterns for planning therapy or physical management needs. In: Bzoch KR, ed. Communicative Disorders Related to Cleft Lip and Palate. 5th ed. Austin, TX: Pro-Ed; 2004:463-491

39 Hanayama EM. Distúrbios da comunicação nos pacientes com sequela de fissura labiopalatina. Rev Soc Bras Cir Craniomaxilofac 2009;12(3):118-124

40 Trost JE. Articulatory additions to the classical description of the speech of persons with cleft palate. Cleft Palate J 1981;18(3): 193-203

41 Yamashita RP. Estudo da pressão aérea intra-oral na fala de indivíduos com fissura palatina congênita. Distúrb Comun 1992; 5(1):155

42 Morley ME. Cleft Palate and Speech. 7th ed. Baltimore, MD: Williams \& Wilkins; 1970 
43 Marino VCC, Dutka JCR, Pegoraro-Krook MI, Lima-Gregio AM. Articulação compensatória associada à fissura de palato ou disfunção velofaríngea: revisão de literatura. Rev CEFAC 2012;14(3): 528-554

44 Trost-Cardamone JE. Diagnosis of specific cleft palate speech error patterns for planning therapy or physical management needs. In: Bzoch KR, ed. Communicative Disorders Related to Cleft Lip and Palate. 4th ed. Austin, TX: Pro-Ed; 1997:313-330

45 Prandini EL, Pegoraro-Krook MI, Dutka JdeC, Marino VCC. Occurrence of consonant production errors in liquid phonemes in children with operated cleft lip and palate. J Appl Oral Sci 2011; 19(6):579-585

46 Scoton MA. Fissura palatina: correlação entre a audição e os distúrbios articulatórios compensatórios. [Dissertação]. Bauru, Brasil: Universidade de São Paulo (USP); 2004

47 Bhatnagar SC, Korabic EW. Neuroanatomy and neurophysiology of central auditory pathways. In: Parthasarathy TK, ed. An Introduction to Auditory Processing Disorders in Children. Mahwah, NJ: LEA; 2006:1-19

48 Chu KM, McPherson B. Audiological status of Chinese patients with cleft lip/palate. Cleft Palate Craniofac J 2005;42(3):280-285

49 Minardi CGC, Souza AC, Netto MP, et al. Auditory abilities in children with cleft lip and/or palate according to Fisher's. Acta Otorrinolaringol Esp 2004;55(4):160-164

50 Barufi L, Netto MP, Ulhôa FM, Rego CF, Feniman MR, Cruz MS. Comportamento de escuta em indivíduos com fissura labiopa- latina: achados preliminares. J Bras Fonoaudiol 2004;5(19): 91-95

51 Lemos IC, Monteiro CZ, Camargo RA, Rissato ACS, Feniman MR. Dichotic listening test (directed attention mode) in children with cleft lip and palate. Braz J Otorhinolaryngol 2008;74(5):662-667

52 Boscariol M, André KD, Feniman MR. Cleft palate children: performance in auditory processing tests. Braz J Otorhinolaryngol 2009; 75(2):213-220

53 Manoel RR, Feniman MR, Buffa MJMB, Maximino LP, Lauris JRP, Freitas JAS. Escuta de crianças com fissura labiopalatina na escola. Arq Int Otorrinolaringol (Impr) 2010;14(3):280-287

54 Lemos ICC, Feniman MR. Sustained Auditory Attention Ability Test (SAAAT) in seven-year-old children with cleft lip and palate. Braz J Otorhinolaryngol 2010;76(2):199-205

55 Moraes TFD, Salvador KK, Cruz MS, Campos CF, Feniman MR Processamento Auditivo em crianças com fissura labiopalatina com e sem histórico de otite. Arq Int Otorrinolaringol (Impr) 2011; 15(4):431-436

56 Araújo LMM, Lauris JRP, Feniman MR. Crianças com fissura labiopalatina e baixo peso ao nascimento auditivos centrais em testes. Arq Int Otorrinolaringol (Impr) 2011;15(3):314-318

57 Feniman MR, Souza TC, Teixeria TS, Mondelli MFCG. Percepção dos pais sobre a habilidade de atenção auditiva de seu filho com fissura labiopalatina: estudo retrospectivo. Arq Int Otorrinolaringol (Impr) 2012;16(1):115-120 